\title{
Palaeoceanographic changes in Hornsund Fjord (Spitsbergen, Svalbard) over the last millennium: new insights from ancient DNA
}

\author{
Joanna Pawłowska ${ }^{1}$, Marek Zajączkowski ${ }^{1}$, Magdalena Lącka ${ }^{1}$, Franck Lejzerowicz ${ }^{2}$, Philippe Esling ${ }^{2,3}$, and \\ Jan Pawlowski ${ }^{2}$ \\ ${ }^{1}$ Institute of Oceanology Polish Academy of Sciences, Sopot, 81-712, Poland \\ ${ }^{2}$ Department of Genetics and Evolution, University of Geneva, Geneva, CH 1211, Switzerland \\ ${ }^{3}$ IRCAM, UMR 9912, Université Pierre et Marie Curie, Paris, France \\ Correspondence to: Joanna Pawłowska (pawlowska@iopan.pl)
}

Received: 30 May 2015 - Published in Clim. Past Discuss.: 13 August 2015

Revised: 3 June 2016 - Accepted: 22 June 2016 - Published: 11 July 2016

\begin{abstract}
This paper presents a reconstruction of climatedriven environmental changes over the last millennium in Hornsund Fjord (Svalbard), based on sedimentological and micropalaeontological records. Our palaeo-investigation was supported by an analysis of foraminiferal ancient DNA (aDNA), focusing on the non-fossilized monothalamous species. The main climatic fluctuations during the last millennium were the Medieval Warm Period (MWP, AD 10001600), the Little Ice Age (LIA, AD 1600-1900) and the modern warming (MW, AD 1900 to present). Our study indicates that the environmental conditions in Hornsund during the MWP and the early LIA (before $\sim$ AD 1800) were relatively stable. The beginning of the LIA ( AD 1600) was poorly evidenced by the micropalaeontological record but was well marked in the aDNA data by an increased proportion of monothalamous foraminifera, especially Bathysiphon sp. The early LIA $(\sim 1600$ to $\sim$ AD 1800$)$ was marked by an increase in the abundance of sequences of Hippocrepinella hirudinea and Cedhagenia saltatus. In the late LIA (after $\sim \mathrm{AD} 1800$ ), the conditions in the fjord became glacierproximal and were characterized by increased meltwater outflows, high sedimentation and a high calving rate. This coincided with an increase in the percentages of sequences of Micrometula sp. and Vellaria pellucidus. During the MW, the major glacier fronts retreated rapidly to the inner bays, which limited the iceberg discharge to the fjord's centre and caused a shift in the foraminiferal community that was reflected in both the fossil and aDNA records.
\end{abstract}

The palaeoceanographic changes in the Hornsund fjord over the last millennium were driven mainly by the inflow of shelf-originated water masses and glacial activity. However, the environmental changes were poorly evidenced in the micropalaeontological record, but they were well documented in our aDNA data. We considerably increased the number of potential proxy species by including monothalamous foraminifera in the palaeoecological studies.

\section{Introduction}

The general outline of climate development over the last millennium is the Medieval Warm Period (MWP), followed by cooling during the Little Ice Age (LIA) and warming in the 20 th and 21st centuries (modern warming; MW). In the European Arctic, the temperature increase during the MWP and MW was correlated with the strong influence of the Atlantic Water inflow and associated heat transport (Wanamaker et al., 2012). In contrast, the weakening of the Atlantic Meridional Overturning Circulation (AMOC) and the lower heat transport to the Arctic might have been responsible for the LIA cooling (Lund et al., 2006). Changes in the Arctic Ocean heat budget were associated with significant changes in the cryosphere, especially the gradual decreases in glacier mass balance and the extent of the sea-ice cover in the last century (e.g. D’Andrea et al., 2012; Jernas et al., 2013).

Fjords are a unique form of coastline that are under the influence of the glaciated land and the ocean. Hence, fjord 
systems are sensitive indicators of climate change phenomena. However, the greatest effort in studying the Holocene history of Svalbard has mainly focused on the shelf area (e.g. Hald et al., 2007; Rasmussen et al., 2012; Łącka et al., 2015). There have been only a few high-resolution studies of the sedimentary record of the Svalbard fjords from the last millennium (e.g. Majewski and Zajączkowski, 2007; Majewski et al., 2009).

The environmental changes during the last millennium observed in the Svalbard shelf were correlated with the interplay of Atlantic and Arctic water masses (Kubischta et al., 2011; Jernas et al., 2013). The Hornsund fjord is strongly influenced by tidewater glaciers, and thus the sedimentary record in this fjord might indicate that enhanced meltwater delivery increased the sediment accumulation and restricted the sea productivity during the periods of glacial retreat. To accurately study climate-driven environmental variability in the past, it is crucial to create a network of proxies that carry different but complementary information.

Foraminifera are widely used as proxies of past and present environmental changes in all types of marine environments. However, palaeoceanographic reconstructions have focused on multi-chambered hard-shelled taxa and have ignored soft-walled, monothalamous species, which often dominate foraminifera assemblages in high latitude regions (Gooday, 2002). Monothalamous foraminifera with organic or predominantly organic test walls are traditionally defined as allogromiids (Gooday, 2002). However, morphological and molecular evidence indicates that "allogromiids" does not refer to a coherent taxonomic group but rather a group that is scattered between several monothalamous clades (Pawlowski et al., 2002; Lejzerowicz et al., 2013a). The group includes organic-walled ("naked") and agglutinated forms of various shapes (Cedhagen et al., 2002). Monothalamous foraminifera with a test build of agglutinated particles are referred to as "saccamminids" or "psammosphaerids". The term "allogromiid" is sometimes applied to monothalamous taxa, irrespective of wall type. Therefore, literature reports might include saccamminids and psammosphaerids in the allogromiids group (Gooday, 2002).

Previous studies have shown that it is possible to consider monothalamous and polythalamous foraminifera (Lejzerowicz et al., 2013b) and other groups of non-fossilized eukaryotes (e.g. Coolen et al., 2006, 2013; Boere et al., 2011) in palaeoecological surveys using an ancient environmental DNA (aDNA) approach. To include monothalamids in palaeoecological studies of Arctic foraminifera, we analysed the ancient foraminiferal DNA record from the last millennium from Hornsund (Pawłowska et al., 2014). The richness of the foraminiferal communities revealed by the molecular analysis was much higher than that in the fossil record, mainly due to the detection of a high number of monothalamous species that were not preserved during the fossilization process and small-size species that are not retained on micropalaeontological sieves.
The aim of this study was to reconstruct the climate-driven environmental changes over the last millennium in Hornsund, with decadal to multi-decadal resolution. The promising results of our previous study (Pawłowska et al., 2014) encouraged us to use our aDNA data to supplement the palaeoclimatic record based on traditional proxies. We evaluated the potential use of monothalamous foraminifera as palaeoceanographic proxies, showing that they might provide valuable environmental information that is complementary to the data obtained with traditional microfossil proxies.

\section{Study area}

Hornsund is the southernmost fjord of Spitsbergen. It is connected to the open sea by a wide no-sill outlet. The fjord's coastline encompasses several glacier-proximal basins that are separated by sills. In its central part, the water depth exceeds $200 \mathrm{~m}$ and varies from 55 to $180 \mathrm{~m}$ in the glacierproximal basins (Fig. 1).

The hydrology of the fjord is under the influence of two main exogenous water masses: the Atlantic Water (AW) and the Arctic Water (ArW). The AW is warm and saline, and its temperature and salinity are usually defined as $\geq 3{ }^{\circ} \mathrm{C}$ and $\geq 34.9$, respectively. The ArW is colder and fresher, and its salinity varies along the Spitsbergen shelf due to the freshwater outflows from fjords (Cottier et al., 2005). The AW and ArW mix over the continental shelf to form the Shelf Transformed Water (STW), which has a temperature and salinity of $1^{\circ} \mathrm{C}$ and 34.7 , respectively. The STW mainly occupies the outer and central parts of the fjord. The Local Water (LW) is formed directly in the fjord by convectional mixing during cooling in the fall and winter or the interaction between the warmer fjord water and glacier fronts (Svendsen et al., 2002).

Seventy percent of the Hornsund catchment area is covered by glaciers (Hagen et al., 1993). The melting of the eight major tidewater glaciers results in an important sediment delivery to the fjord. The modern sediment accumulation rate varies from 0.5 to $0.7 \mathrm{~cm} \mathrm{yr}^{-1}$ in the central and inner parts, respectively (Szczuciński et al., 2006).

During the last millennium, Hornsund was subjected to major environmental changes, including the MWP, cooling and glacial advances during the LIA, which culminated in the period from AD 1600 to 1900 , and warming and massive glacial retreats during the 20th and 21st centuries (MW; Ziaja, 2001; Pälli et al., 2003). These changes were correlated with the variability in the inflow of the cold ArW and warm $\mathrm{AW}$ and were recorded in foraminifera assemblages and the stable isotope compositions from foraminiferal tests (Majewski et al., 2009).

The previous aDNA-based investigation on the foraminiferal fauna from Hornsund (Pawłowska et al., 2014) focused mainly on the hard-shelled species. The aDNA sequences assigned to testate foraminifera constituted 142 out of 394 OTUs (operational taxonomic units). The 


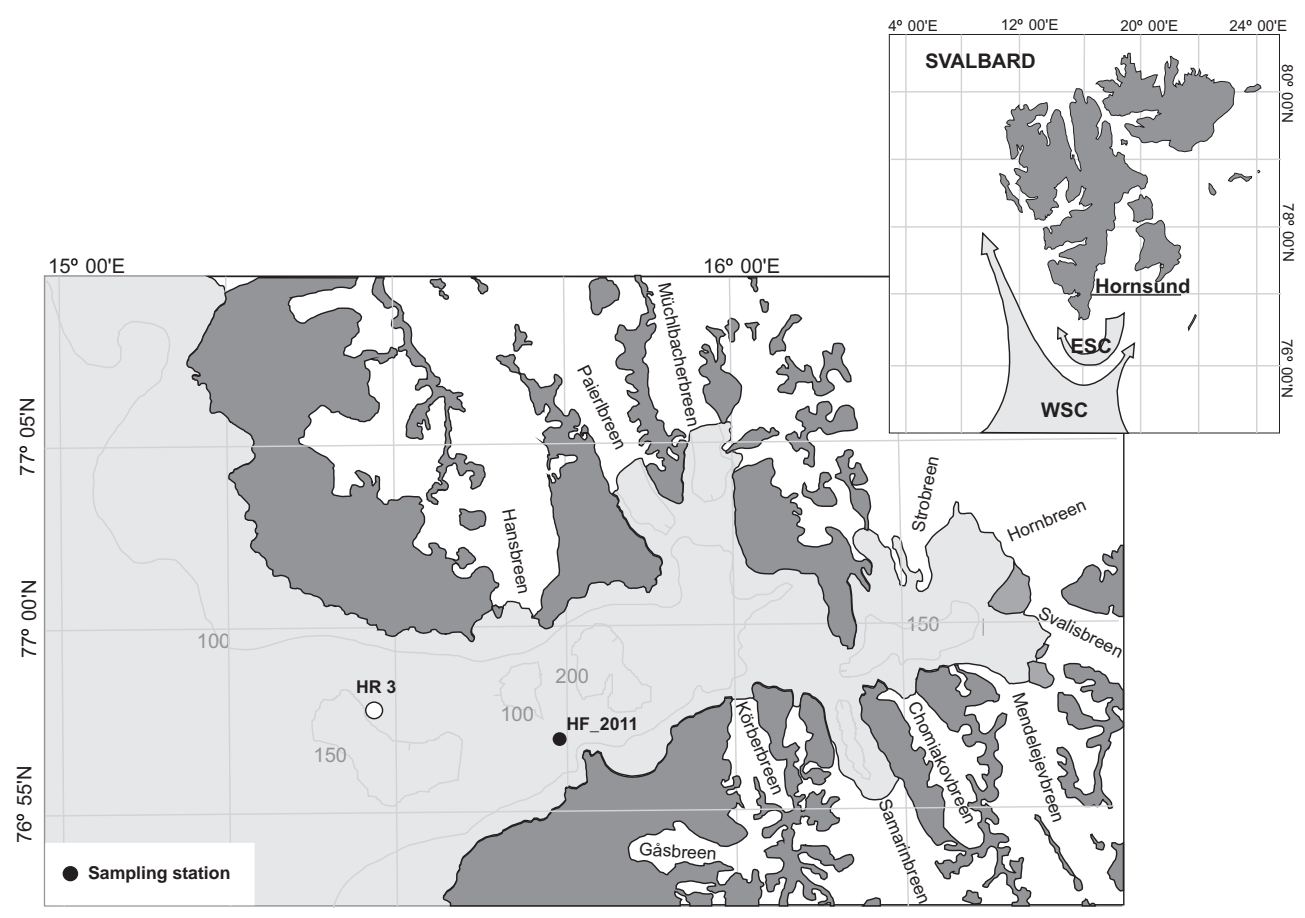

Figure 1. Bathymetric map of Hornsund with sampling station HF 2011. The position of core HR 3 studied by Majewski et al. (2009) is shown. Glaciers are shown in white. WSC - West Spitsbergen Current; ESC - East Spitsbergen Current.

microfossil record comprised 45 species and $57 \%$ of them were also found in the molecular data. Foraminifera detected by both approaches included species reported for Hornsund by previous investigations (e.g. Hald and Korsun 1997; Pogodina, 2005), e.g. Cassidulina spp., Cibicides lobatulus, Nonionellina labradorica, Elphidium excavatum, Reophax scorpiurus, Reophax sp., Spiroplectammina sp., Cribrostomoides crassimargo and Quinqueloculina sp. Among these, Cassidulina spp., C. lobatulus and E. excavatum were noted frequently in microfossil and sequence data, making up 8.8, 3.4 and $2.5 \%$ of the sequences, respectively. However, there were four species that were also frequent in the fossil record but were represented by less than $1 \%$ of aDNA sequences (N. labradorica and C. crassimargo) or were not sequenced (B. frigida and I. helenae). On the other hand, some taxa belonging to the genera Stainforthia, Spiroplectammina and Reophax were rarely found in the microfossil assemblage but were represented by numerous sequences. The discrepancies between the records were explained by biological features of certain foraminiferal species and by the differences in characteristics of these two approaches (i.e. the analytical procedures).

\section{Material and methods}

A $2 \mathrm{~m}$ long sediment core HF_2011 was taken with a gravity corer from the R/V Oceania during a cruise in July 2011. The sampling station was located in the central basin of the fjord, in a flat seabed area at a depth of $135 \mathrm{~m}\left(76^{\circ} 57.238^{\prime} \mathrm{N}\right.$, $15^{\circ} 41.782^{\prime}$ E; Fig. 1). The core was subsampled onboard for aDNA analyses and frozen at $-20^{\circ} \mathrm{C}$ until further analyses were conducted at the Institute of Oceanology, Polish Academy of Sciences (Sopot, Poland), as described in Pawłowska et al. (2014). After thawing at $4{ }^{\circ} \mathrm{C}$, the core was split into two parts longitudinally, and each half was cut into $1 \mathrm{~cm}$ slices for micropalaeontological and sedimentological analyses. Carbonate shells were picked for accelerator mass spectrometry (AMS) ${ }^{14} \mathrm{C}$ dating.

\subsection{Grain size and stable isotope analyses}

The grain size analysis of the sediment slices was conducted using a Mastersizer 2000 laser analyser coupled with a HydroMU device (Malvern Instruments, Malvern, UK) and supported by the wet sieving of fractions larger than $250 \mu \mathrm{m}$. The granulometric data were analysed with the use of the GRADISTAT 8.0 software program (Blott and Pye, 2001). Dried and weighted sediment fractions $>250$ and $500 \mu \mathrm{m}$ were used for ice-rafted debris (IRD) analyses, and at least 500 mineral grains from each fraction were counted under a stereo microscope. The IRD was expressed as the number of grains per gram of sediment (grains $\mathrm{g}^{-1}$ ) and number of grains per square centimetre per year (grains $\mathrm{cm}^{-2} \mathrm{yr}^{-1}$ ).

Stable isotope analyses were performed on foraminiferal tests selected from 54 sediment layers. From each layer, 10 to 12 well-preserved specimens of Cibicidoides lobatulus were selected. The measurements were performed on a Finnigan 
MAT 253 mass spectrometer coupled to a Kiel IV carbonate preparation device (Thermo Fisher Scientific, University of Florida). The resulting values were compared to isotopic standard NBS-19 and expressed in standard $\delta$ notation relative to Vienna Pee Dee Belemnite (VPDB).

\subsection{Foraminiferal counts and molecular analysis}

Prior to the analysis of the fossil foraminiferal assemblages, 74 selected sediment samples were dried, weighed and wet-washed through sieves with 500 and $100 \mu \mathrm{m}$ openings. Each sample was divided using a dry microsplitter, and at least 300 specimens from each sample were counted. The foraminiferal counts were reported as percentages of the total assemblage and as the number of individuals per square centimetre per year. The fossil foraminifera assemblage was analysed with an orthogonally rotated (varimax) Q-mode principal component (PC) analysis, using commercially distributed software (SYSTAT 11). Taxa with abundances $>2 \%$ of the total assemblage in at least one sample were analysed. Each PC was defined by the dominant (and eventually accessory) species. The PCs were referred to foraminiferal assemblages (FAs) named after the dominant species. The PC scores showed the contribution of the selected species to each PC. PC loadings higher than 0.4 were regarded as statistically significant (Malmgren and Haq, 1982).

The analysis of molecular data from 12 selected layers was described in detail in Pawłowska et al. (2014). Briefly, the total DNA of each of the 12 sediment samples was extracted with a PowerSoil DNA kit (MoBio). A 3' SSU rDNA fragment including the foraminifera-specific $37 \mathrm{f}$ hypervariable region (Pawlowski and Lecroq, 2010) was PCR-amplified from environmental DNA. The SSU rDNA sequences were then obtained either based on cloning and Sanger sequencing or after library preparation and Illumina high-throughput sequencing.

For the cloning-based Sanger sequencing, the environmental DNA was PCR-amplified with s14F3 forward primer combined with s17, s15.2 or s15ROTEX as reversed primers. The sizes of the resulting fragments were of ca. $400 \mathrm{bp}$ for s14F3/s17 and ca. $200 \mathrm{bp}$ for both the s14F3/s 15.2 and s14F3/s15ROTEX amplifications. Nested PCR was performed for samples with s14F3/s17 with the use of a s14F1/s17 primer combination. Positive and controlled PCR products of expected sizes were cloned and Sanger sequenced as in Pawlowski et al. (2011). The resulting raw sequences were manually corrected and edited using Codon Code Aligner and SeaView 4.0 (Gouy et al., 2010).

For high-throughput sequencing (HTS), s14F0 and s15 primers tagged with unique sequences of 5 nucleotides were used. The size of the obtained fragment was ca. $100 \mathrm{bp}$. The amplicons were quantified and pooled in equimolar quantities. A library preparation was performed using a TruSeq library-preparation kit (Illumina) and was loaded onto a HiSeq instrument for a paired-end HTS run of $2 \times 100 \mathrm{cy}-$ cles at Fasteris SA (Plan-les-Ouates, Switzerland). The processing of the HTS sequence data, including quality filtering, sample demultiplexing, strict dereplication into unique sequences and OTU selection, was realized according to Lejzerowicz et al. (2013a), except that unique sequences that were composed of up to 10 reads in a sample were removed. The results were presented as OTU-to-sample tables and transformed in terms of the number of OTUs and the relative abundance $(\%)$ of sequences.

\section{Sediment dating}

The age of the studied core was estimated based on highprecision AMS ${ }^{14} \mathrm{C}$ dating performed on bivalves shells, as presented in Pawłowska et al. (2014). Eleven shells identified to the highest possible taxonomic level were selected and processed on a model 1.5 SDH-Pelletron "Compact Carbon AMS" (Poznań Radiocarbon Laboratory, Poland). The dates were converted into calibrated ages using the CALIB Rev. 7.0.2 Beta calibration program (Stuiver and Reimer, 1993) and the Marine13 calibration dataset (Reimer et al., 2013). The difference $\Delta R$ in the reservoir age correction of $105 \pm 24$ was applied (Mangerud et al., 2006).

Four of the 11 samples were used to establish an approximate age model for the sediment core. The upper-most sample contained post-bomb carbon, which indicates a post-1960 age. Samples located in the middle part of the core revealed ages that were not in chronological order. All the samples (shells) revealing age reversals were excluded from the age model as they were likely redeposited (Table 1). Samples out of chronological order occurred at the depths of $\sim 15-55$ and $\sim 80-115 \mathrm{~cm}$, and therefore it is likely that these sediment intervals represent major redeposition events. The agedepth model was made with the use of the CLAM-R software program (Blaauw, 2010; Fig. 2). The age of the oldest layer was estimated to be $\sim$ AD 965 . The sediment accumulation rate (SAR) in the deepest part of the core (i.e. before $\mathrm{AD} 1800$; up to $120 \mathrm{~cm}$ ) ranged from 0.1 to $0.125 \mathrm{~cm} \mathrm{yr}^{-1}$. At $\sim$ AD $1800(120 \mathrm{~cm})$, the SAR increased to $1 \mathrm{~cm} \mathrm{yr}^{-1}$. In the upper layers (after $\sim \mathrm{AD} 1850 ; 70 \mathrm{~cm}$ ), the SAR decreased to $0.3 \mathrm{~cm} \mathrm{yr}^{-1}$.

\section{Foraminifera as environmental indicators}

Due to the differences in the ecological tolerances of particular species, foraminifera are indicators of glaciomarine conditions, Atlantic and Arctic water masses and bottom currents. Herein, we followed the classification that Majewski et al. (2009) established based on ecological and palaeoenvironmental studies from Greenland, Svalbard, Novaya Zemlya and the Kara Sea region (see Majewski et al., 2009 , and references therein).

The glaciomarine group comprised Cassidulina reniforme, Elphidium excavatum and Quinqueloculina stalk- 
Table 1. Raw AMS ${ }^{14} \mathrm{C}$ and calibrated dates used for the age model (after Pawłowska et al., 2014). nd.: "not determined".

\begin{tabular}{rllrc}
\hline $\begin{array}{r}\text { Sediment } \\
\text { depth }(\mathrm{cm})\end{array}$ & Material & $\begin{array}{l}\text { Raw AMS } \\
14 \mathrm{C}\end{array}$ & $\begin{array}{r}\text { Calibrated years } \\
\mathrm{BP} \pm 2 \sigma\end{array}$ & $\begin{array}{c}\text { Years AD used } \\
\text { in age model }\end{array}$ \\
\hline 8.5 & Cilliatocardina cilliatea & $\begin{array}{l}105.58( \pm 0.35) \mathrm{pMC} \\
33.5\end{array}$ & $\begin{array}{r}-10 \text { to }-35 \\
10605-11040\end{array}$ \\
48.5 & Gastropod nd. & $9990( \pm 50) \mathrm{BP}$ & $40-240$ & \\
56.5 & Nuculana pernula & $880( \pm 25) \mathrm{BP}$ & $315-485$ & \\
70.5 & Bathyarca glacialis & $580( \pm 30) \mathrm{BP}$ & $1-150$ & 1850 \\
89.5 & Macoma calcarea & $765( \pm 30) \mathrm{BP}$ & $230-420$ & \\
106.5 & Cilliatocardina cilliatea & $760( \pm 30) \mathrm{BP}$ & $230-420$ & \\
109.5 & Cilliatocardina cilliatea & $735( \pm 25) \mathrm{BP}$ & $180-380$ & \\
122.5 & Gastropod nd. & $615( \pm 30) \mathrm{BP}$ & $40-250$ & 1800 \\
166.5 & Hiatella arctica & $1075( \pm 30) \mathrm{BP}$ & $500-630$ & 1450 \\
173.5 & Macoma calcarea & $1145( \pm 30) \mathrm{BP}$ & $540-670$ & 1400 \\
\hline
\end{tabular}

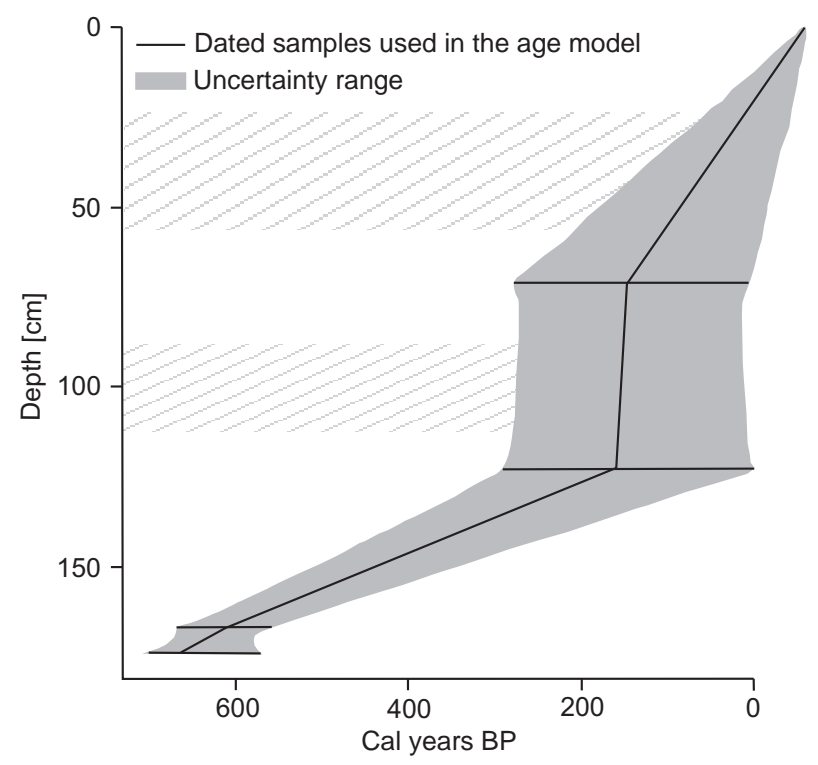

Figure 2. Age model of the studied core. The black line indicates the age-depth model derived from a linear interpolation. The grey fields show the probability distributions of calendar dates obtained by the calibration of individual ${ }^{14} \mathrm{C}$ dates used for the age model. The shaded areas mark sediment intervals which most likely represent major redeposition events (after Pawłowska et al., 2014, modified).

eri. The characteristic species of the Atlantic water mass are Nonionellina labradorica, Bolivina pseudopunctata, Buccella frigida, Adercotryma glomerata, Ammotium cassis and Recurvoides turbinatus. We decided to exclude Reophax fusiformis and Reophax pilulifer from this group because there were only two specimens of $R$. fusiformis in the HF_2011 core, and $R$. pilulifer was not reported. The Arctic water group was composed of Islandiella norcrossi, Elphidium spp. (excluding E. excavatum), Stainforthia feylingi, Stainforthia loeblichii, Spiroplectammina bi- formis and Spiroplectammina earlandi. We decided to add Islandiella helenae to this group based on Kelly et al. (1999). The bottom current indicator group consisted of Cibicidoides lobatulus and Astrononion gallowayi.

\section{Results}

\subsection{Sediment age and characteristics}

The sediment was mainly composed of glaciomarine mud, with low sand content. Before AD $1600(145 \mathrm{~cm})$, the mean grain size fluctuated slightly, except for one peak at $\sim \mathrm{AD} 1450(160 \mathrm{~cm})$, which reached $4.5 \varphi$. In $\sim \mathrm{AD} 1600$, the mean grain size increased slightly to $6.2 \varphi$. After AD $1800(122 \mathrm{~cm})$, it varied within a broader range of values and presented three slight peaks between AD 1800 and $1850(120,100$ and $70 \mathrm{~cm})$. A decrease in the mean grain size was observed from the middle to the end of the 20th century (25-0 cm; Fig. 3).

From AD 1000 to $1800(200-122 \mathrm{~cm})$, the IRD flux was relatively stable and did not exceed 2 grains $\mathrm{cm}^{-2} \mathrm{yr}^{-1}$. After that period, the IRD delivery increased considerably, reaching up to 28 grains $\mathrm{cm}^{-2} \mathrm{yr}^{-1}$. From $\sim 1900$ to the end of the 20th century, the IRD flux varied from 0.24 to 10 grains $\mathrm{cm}^{-2} \mathrm{yr}^{-1}$ (Fig. 3). There were three distinctive periods when the amount of IRD in the sediment considerably increased (Fig. 3): (1) at the transition from the MWP to the LIA (160-130 cm; up to 30 grains $^{-1}$ ), (2) in the late LIA $\left(115-80 \mathrm{~cm}\right.$; up to 24 grains $\left.\mathrm{g}^{-1}\right)$ and (3) in the early 20th century (60-20 cm; up to 24 grains $\mathrm{g}^{-1}$ ).

\subsection{Stable isotopes}

From AD 1000 to $1600(200-145 \mathrm{~cm}), \delta^{18} \mathrm{O}$ showed relatively stable values varying slightly from $2.63 \%$ vs. VPDB to $3.32 \%$ vs. VPDB. After AD 1600, it fluctuated distinctly from 2.23 to $3.50 \%$ vs. VPDB. Larger $\delta^{18} \mathrm{O}$ values were observed before AD 1600 and in the 20th century. The pe- 


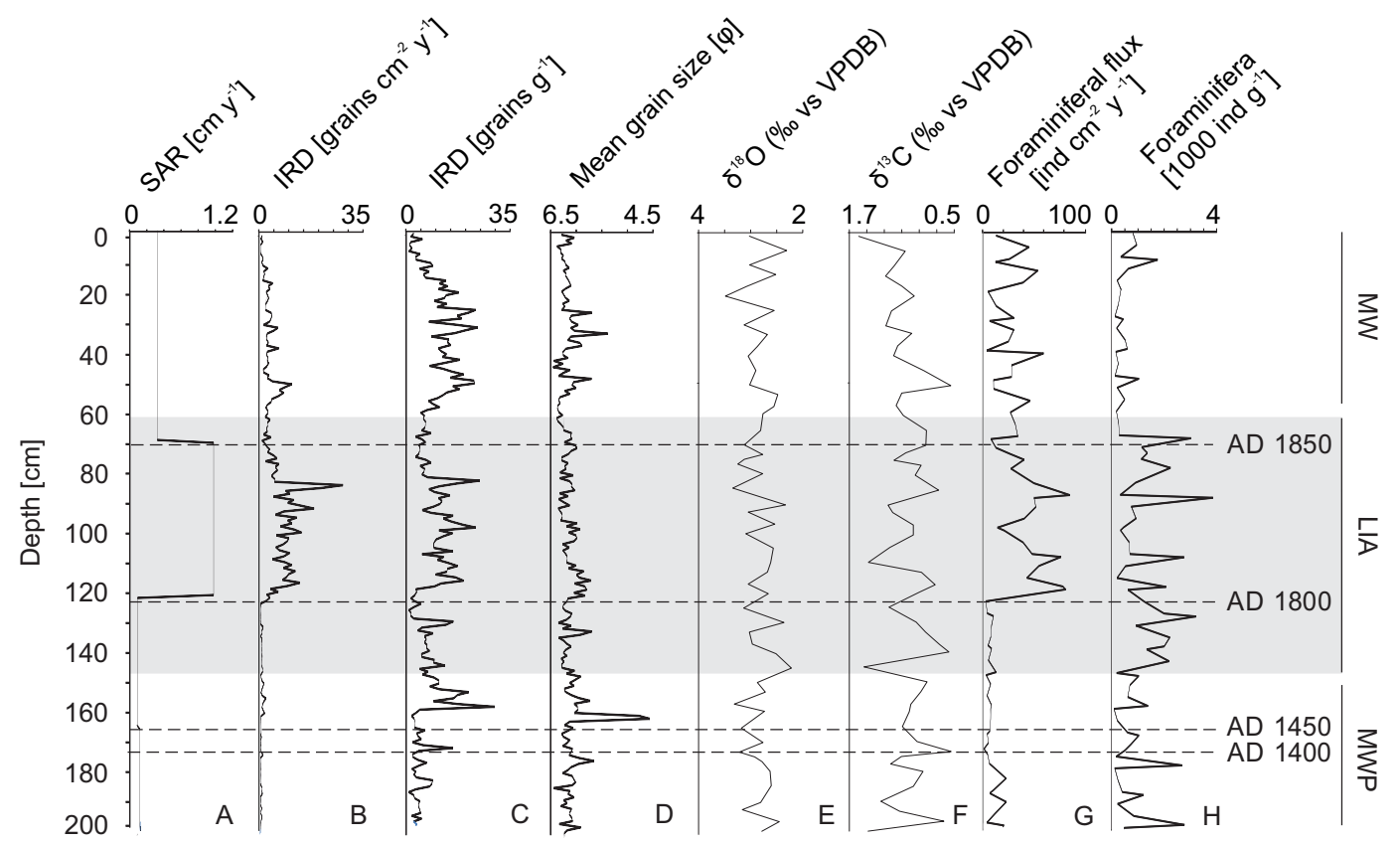

Figure 3. Sediment accumulation rate (a), IRD delivery, expressed as IRD flux (b) and number of IRD grains per gram of sediment (c), mean grain size (d), stable oxygen (e) and carbon (f) isotopes, flux of total fossil foraminifera (g) and number of foraminifera per gram of sediment (h). MWP: Medieval Warm Period; LIA: Little Ice Age; MW: modern warming. The time ranges of the MWP, LIA and MW are presented after Majewski et al. (2009).

riod from $\mathrm{AD} 1600$ to $1900(145-60 \mathrm{~cm})$ was characterized by a smaller $\delta^{18} \mathrm{O}$, with significant peaks at the beginning of the LIA $(\sim \mathrm{AD} 1600 ; 145 \mathrm{~cm})$ and during the late LIA $\left(50\right.$ and $90 \mathrm{~cm}$ ). The measured values of $\delta^{13} \mathrm{C}$ varied from $0.54 \%$ vs. VPDB to $1.59 \%$ vs. VPDB and fluctuated along the core. The most important fluctuations occurred between $\sim \mathrm{AD} 1600$ and $1900(145-60 \mathrm{~cm})$, with $\delta^{13} \mathrm{C}$ values ranging from 0.54 to $1.48 \%$ ovs. VPDB (Fig. 3).

\subsection{Foraminiferal abundance and taxonomic composition revealed by the fossil record}

The foraminiferal flux varied from 1 to 86 ind. $\mathrm{cm}^{-2} \mathrm{yr}^{-1}$. The most noticeable shift occurred at $\sim$ AD $1800(120 \mathrm{~cm})$, when it increased from 2.8 to 81 ind. $\mathrm{cm}^{-2} \mathrm{yr}^{-1}$ (Fig. 3). The number of foraminifera per gram of sediment varied from 86 to 3838 ind. $\mathrm{g}^{-1}$. The highest values were observed before $\sim$ AD $1850(70 \mathrm{~cm})$. After AD 1850, the number of foraminifera declined and did not exceed 1742 ind. $\mathrm{g}^{-1}$ (Fig. 3).

A total of 28771 individuals were assigned to 72 species and 38 genera. Most of the species belonged to Rotaliida (34), Textulariida (12) and Lagenida (12). The other species were identified as Miliolida (10), Lituolida (2) and Globigerinida (Table S1 in the Supplement). The most abundant species were Elphidium excavatum, Cassidulina reniforme, Cibicidoides lobatulus and Nonionellina labradorica (Fig. 4). The fossil assemblage was strongly dominated by $E$. excavatum and C. reniforme, which together comprised up to $82 \%$ of the total abundance. The abundance of $C$. lobatulus and $N$. labradorica varied slightly along the core, and no evident faunal changes were observed. The highest percentages of $N$. labradorica were noted after $\sim \mathrm{AD} 1800$ and at the beginning of the 20th century $(110,50$ and $25 \mathrm{~cm})$, when its relative abundance reached up to $25 \%$. The highest percentages of C. lobatulus were noted before AD $1600(145 \mathrm{~cm})$, and a notable decrease in that species occurred in the latter part of the 20th century $(25-0 \mathrm{~cm})$. The percentage of agglutinated taxa did not exceed $25 \%$ and reached its highest values between AD 1600 and $1800(145-120 \mathrm{~cm})$ and after $\sim$ AD 1930 ( 25 cm; Fig. 4).

The proposed four-factor PC explained $98.5 \%$ of the total variability in the tested dataset. The most important PC analysis assemblages were (1) the E. excavatum FA, which explained $40.8 \%$ of the total foraminiferal variance; (2) the $C$. reniforme FA, with E. excavatum as an accessory species, which explained $34.8 \%$ of the variance; (3) the $N$. labradorica FA, with $C$. lobatulus as an accessory species, which explained $20.1 \%$ of the variance; and (4) the C. lobatulus FA, which explained $2.8 \%$ of the total variance (Table 2). The HF_2011 core was dominated by the E. excavatum FA and the $C$. reniforme FA throughout. The E. excavatum FA showed the highest factor loadings during the LIA (i.e. between AD 1600 and 1900). In the uppermost part of the core, the E. excavatum factor loadings decreased, and the role of the $C$. reniforme FA increased. The $N$. labradorica FA 


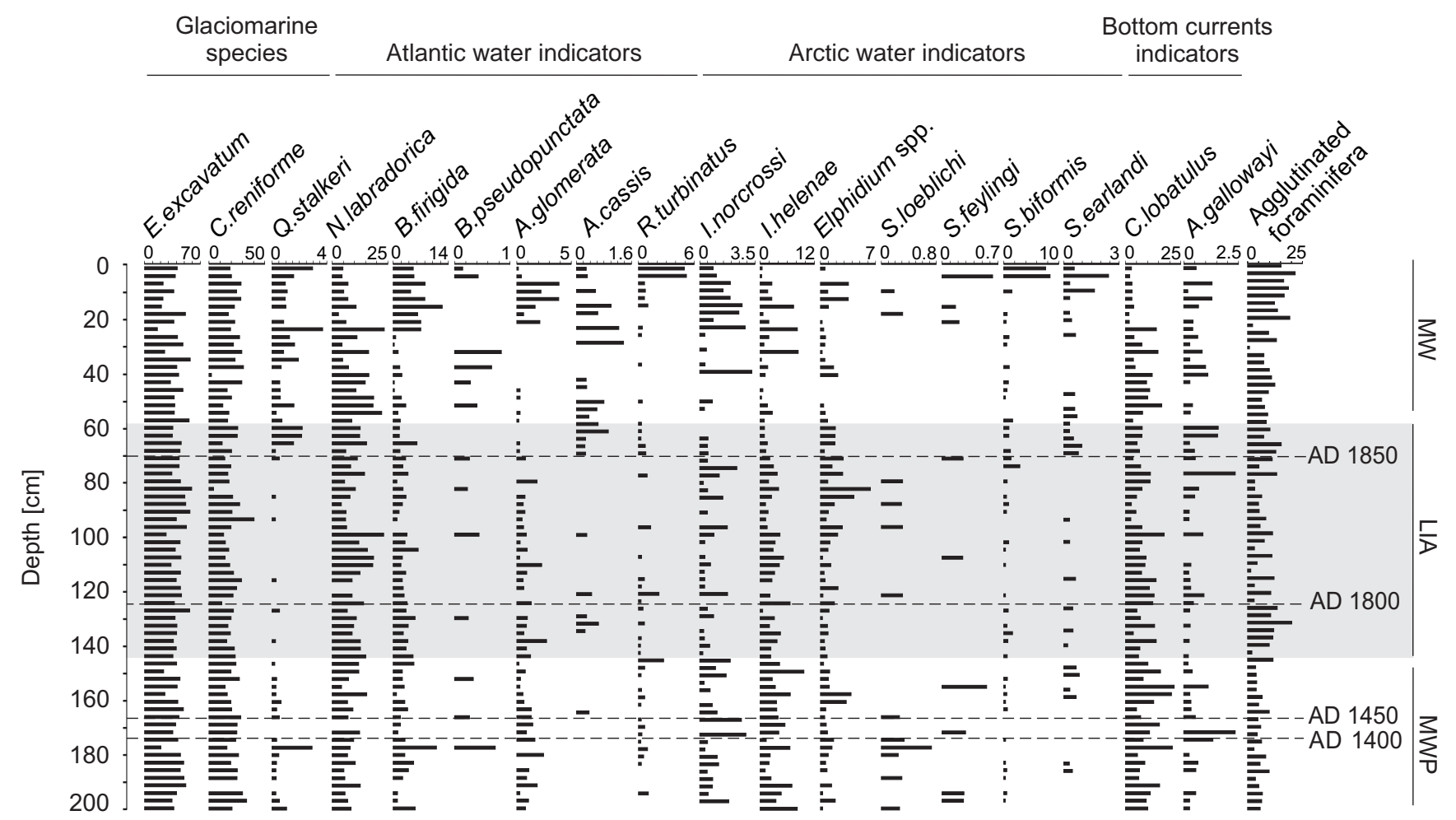

Figure 4. The abundances of selected foraminifera species expressed as percentages (\%) of the total assemblage. The foraminiferal taxa were grouped based on their ecological tolerances (see Sect. 5: "Foraminifera as palaeoenvironmental indicators"). MWP: Medieval Warm Period; LIA: Little Ice Age; MW: modern warming. The time ranges of MWP, LIA and MW are presented after Majewski et al. (2009).

Table 2. PC scores and percent of total variance explained by four-factor principal component analysis. The contribution of each analysed species is shown, and species significant for particular assemblages are marked in bold.

\begin{tabular}{lrrrr}
\hline & PC 1 & PC 2 & PC 3 & PC 4 \\
\cline { 2 - 5 } Percent of total variance explained & $40.8 \%$ & $34.8 \%$ & $20.1 \%$ & $2.8 \%$ \\
\hline Adercotryma glomerata & -0.1857 & -0.13401 & -0.75184 & -0.06062 \\
Buccella frigida & -0.40847 & 0.081688 & -0.13456 & -0.34934 \\
Cassidulina reniforme & -1.44681 & 2.923605 & 0.894126 & 0.480619 \\
Cibicidoides lobatulus & -0.22008 & -1.29993 & 1.821983 & 2.252356 \\
Cribrostomoides crassimargo & 0.13799 & 0.418817 & -0.63454 & -1.15662 \\
Elphidium bartletti & -0.06081 & -0.41644 & -0.64903 & 0.130446 \\
Elphidium excavatum & 3.21345 & 1.108558 & 0.281919 & 0.526077 \\
Islandiella helenae & -0.39509 & -0.39785 & 0.267723 & 0.366261 \\
Islandiella norcrossi & -0.21596 & -0.31512 & -0.5112 & 0.091585 \\
Nonionellina labradorica & 0.124046 & -0.71182 & 2.242218 & -2.40609 \\
Quinqueloculina stalkeri & -0.23152 & -0.30084 & -0.57036 & 0.05742 \\
Recurvoides turbinatus & -0.15527 & -0.33373 & -0.6666 & 0.055335 \\
Spiroplectammina biformis & -0.08015 & -0.30205 & -0.80459 & 0.020384 \\
Spiroplectammina sp. & -0.07563 & -0.32089 & -0.78525 & -0.00781 \\
\hline
\end{tabular}

was significant during the MWP and the early LIA (before $\sim \mathrm{AD} 1800$ ) and was not significant during the late LIA (after $\sim$ AD 1850). The $N$. labradorica factor loadings started to increase at the beginning of the 20th century. The C. lobatu- lus FA was significant only in two layers dated to the MWP (Fig. 5). 


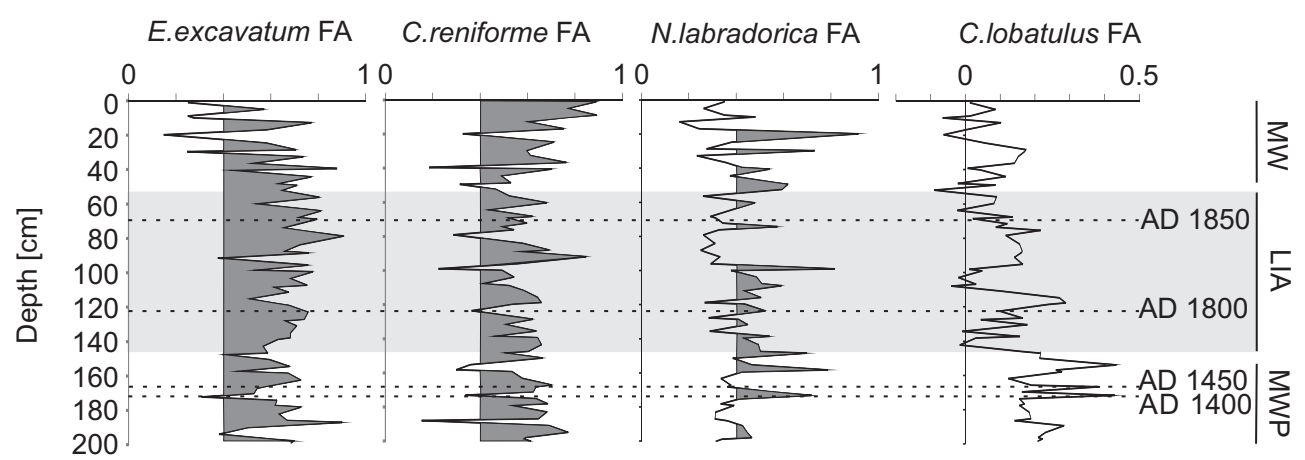

Figure 5. PC loading values for four foraminiferal assemblages found in the HF_2011 core. The statistically significant loadings are marked in grey. MWP: Medieval Warm Period; LIA: Little Ice Age; MW: modern warming. The time ranges of the MWP, LIA and MW are presented after Majewski et al. (2009).

\subsection{Foraminifera in the ancient DNA record}

The results of the aDNA analysis are described in detail in Pawłowska et al. (2014). Herein, we summarize the results, focusing on monothalamous foraminifera.

We used Sanger and high-throughput sequencing (HTS) to obtain 717 and 8700815 sequences, respectively. A total of 394 OTUs were obtained from the sequence clustering. The majority of the OTUs were assigned to Monothalamea (96 OTUs) and Rotaliida (93 OTUs). The remaining OTUs were assigned to Textulariida (33 OTUs), Miliolida (10 OTUs), Globothalamea (10 OTUs), Robertinida (1 OTU) and Globigerinida (5 OTUs); 146 OTUs remained unassigned (Table S2). Although the sequences of the species that dominated the fossil record were present in most of the samples, their abundances did not reflect the abundances in the fossil specimens (see Pawłowska et al., 2014).

The 96 OTUs assigned to monothalamids comprised $39.4 \%$ of the sequences. The percentage of monothalamous sequences varied along the core from 3.5 to $65 \%$. (Fig. 5) There were seven OTUs constituting more than $3 \%$ of all the sequences in at least one sample. They were referred to Bathysiphon sp. (clade BM), Micrometula sp. (clade BM, two OTUs), Toxisarcon sp. (clade C) and monothalamous foraminifera of undetermined phylogenetic origin (three OTUs; Table S2).

Monothalamid sequences were assigned to 14 clades, including 10 that were represented by more than $5 \%$ of the monothalamid sequences in at least one sample. The assemblage of monothalamous foraminifera was strongly dominated by clade BM (genera Micrometula and Bathysiphon), which together comprised up to $90 \%$ of the sequences of monothalamids (Fig. 5). Bathysiphon sp. was the most abundantly sequenced in the samples spanning the MWP and the early LIA, whereas sequences of Micrometula sp. dominated in the samples spanning the 20th century. The monothalamous assemblage during the MWP was dominated by Toxisarcon sp. and environmental monothalamous sequences belonging to clade V. The early LIA (AD 1600-1800; 150-
$125 \mathrm{~cm}$ ) was marked by an increased proportion of sequences of Hipocrepinella hirudinea (clade D) and Cedhagenia saltatus (clade $\mathrm{O}$ ). The monothalamous assemblage during the beginning of the MW ( $\sim$ AD 1900; $50 \mathrm{~cm}$ ) was strongly dominated by Micrometula sp. (which constituted up to $75 \%$ of the monothalamous sequences), together with Vellaria pellucidus. In the late MW, a high number of monothalamid sequences occurred that belonged to environmental clades or were of undetermined phylogenetic origin (Fig. 6).

\section{Discussion}

Previous studies on the Svalbard Holocene history have reported "unstable environmental conditions" during the last thousand years (e.g. Berben et al., 2014; Groot et al., 2014), reflecting the major climatic changes: the MWP $(\sim$ AD 900 $1500)$, the LIA ( $\sim$ AD 1500-1900) and the MW $(\sim 1900$ to present) (Oerlemans, 2005). The Svalbard ice core records and sediment records from the shelf adjacent to Hornsund suggested that prolonged cooling started $\sim \mathrm{AD} 1600$, and the most severe conditions occurred during the 19th century (Isaksson et al., 2003; Majewski et al., 2009). However, the reconstruction of the Earth's surface air temperature from Svalbard (Divine et al., 2011) constituted the cooling stage between AD 800 and 1800, with no clear signs of the onset of the LIA. Our foraminiferal and sedimentological records from Hornsund matched the trend described by Divine et al. (2011), as it revealed a sharp change in environmental conditions at $\sim \mathrm{AD} 1800$.

\subsection{The Medieval Warm Period and the early Little Ice Age ( $\sim$ AD 1000 to $\sim 1800$ )}

The period from $\sim$ AD 1000 to $\sim 1800$ was characterized by low and stable fluxes of IRD and foraminifera and slightly heavier $\delta^{18} \mathrm{O}$ (Fig. 3). This might indicate the influence of warmer and more saline waters, probably of Atlantic origin, and low glacial activity (Jernas et al., 2013). The fossil foraminiferal assemblage was fairly stable during the MWP 


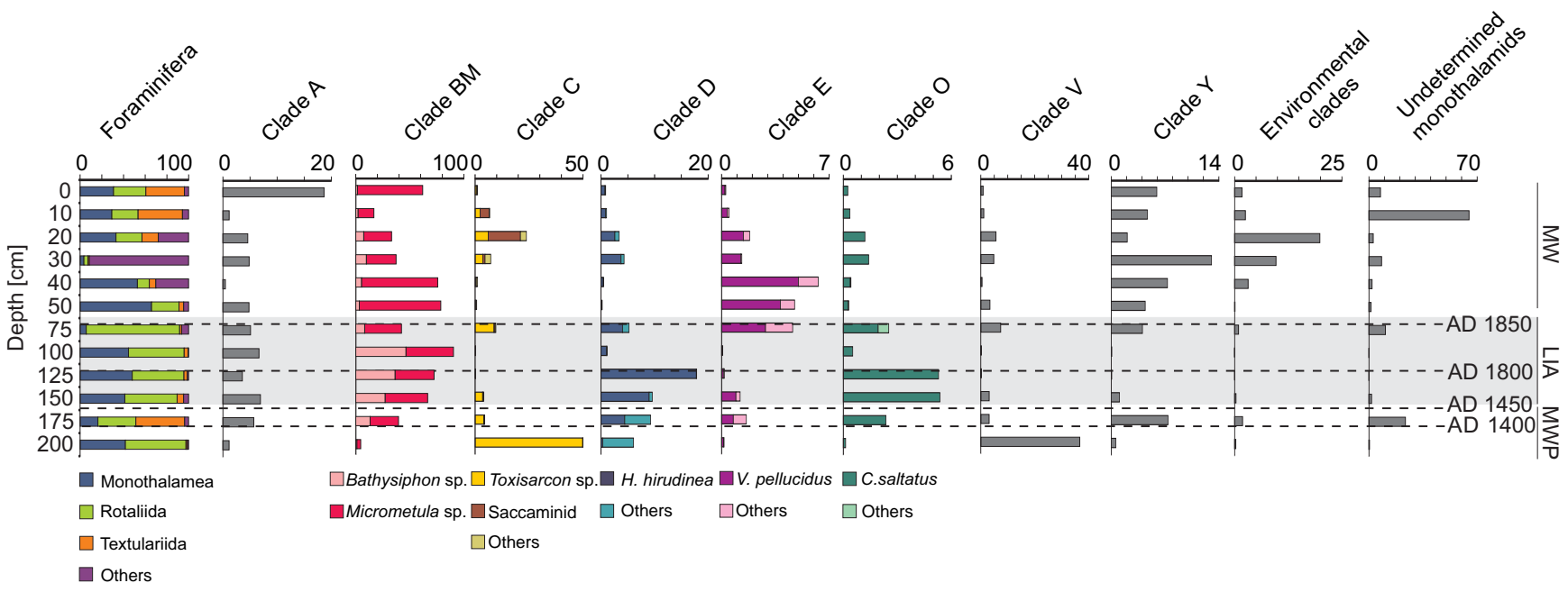

Figure 6. The relative abundance of the monothalamid sequences, expressed as the percentage of all foraminiferal sequences, and the composition of the monothalamid assemblage, expressed as percentages of sequences within clades. Clades that constitute more than $5 \%$ of the monothalamid sequences in at least one sample are presented. "Environmental clades" relate to foraminifera known only from environmental sequencing. The time ranges of the MWP, LIA and MW are presented after Majewski et al. (2009).

(i.e. before $\mathrm{AD} 1600$ ) and there was no clear evidence of faunal change. Conversely, the foraminiferal aDNA record featured a high percentage of Toxisarcon sp. (clade C) at $\sim$ AD 1000 (Fig. 5). As reported by Gooday et al. (2005), Toxisarcon sp. are commonly found in the Svalbard fjords. In the case of our study, the increase in the Toxisarcon sp. percentage coincided with the peak of light $\delta^{18} \mathrm{O}$, followed by lighter $\delta^{13} \mathrm{C}$, which might suggest the presence of a highly productive zone of frontal contact of the AW and ArW water masses. Voltski et al. (2014) noted the presence of diatom frustules in the cytoplasm of Toxisarcon sp. Therefore, we concluded that the occurrence of Toxisarcon sp. might be related to the phytoplankton-originated organic matter input.

Our data showed a slight peak of lighter $\delta^{18} \mathrm{O}$ at $\mathrm{AD} 1600$ (Fig. 3), which could indicate an increase in meltwater delivery to Hornsund, but it was not followed by increases in sediment accumulation and IRD flux. Therefore, we concluded that lighter $\delta^{18} \mathrm{O}$ at $\sim \mathrm{AD} 1600$ showed the increased ArW inflow from the Barents Sea to the Svalbard shelf and Hornsund, which is in agreement with previous $\delta^{18} \mathrm{O}$ and fossil foraminiferal records obtained from the outer fjord (Majewski at al., 2009). This event occurred within a period of significant climate changes connected to the transition from the MWP to the LIA. The Humlum et al. (2005) investigation of the frozen in situ vegetation below Longyearbyen glacier (central Spitsbergen) indicated the advance of that glacier during the last $\sim 1100$ years. Based on the terrestrial record from Hornsund, the MWP was interrupted 600 years ago by an advance of glaciers (Marks and Pękala, 1986; Linder et al., 1990) that lasted until the beginning of the 20th century.

The most pronounced changes that occurred at $\sim \mathrm{AD} 1600$ in the HF_2011 fossil assemblage were slight peaks in the abundances of $N$. labradorica, I. norcrossi and I. helenae.
Moreover, an increase in the percentage of agglutinated taxa was noted between AD 1600 and 1800 (Fig. 4). Nonionellina labradorica is an AW indicator usually found in relatively warm and saline waters (Lloyd, 2006; Majewski et al., 2009). However, the abundances of these three species seemed to be controlled more by the food supply than by water temperatures (Hald and Korsun, 1997; Lloyd, 2006; Ivanova, 2008). The presence of Islandiella spp might indicate a highly productive environment related to the polar front (Steinsund, 1994). This supports the evidence of the inflow of the colder

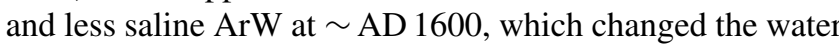
mass balance and productivity in the fjord.

The foraminiferal flux before $\sim \mathrm{AD} 1800$ was low (Fig. 3) and could be explained by the presence of species with low fossilization potential, e.g. agglutinated taxa (Wollenburg and Kuhnt, 2000). The percentage of agglutinated taxa was relatively low during the MWP and increased significantly after AD 1600 (Fig. 4), which likely reflected the inflow of the ArW and relatively low glacial activity (Hunt and Corliss, 1993; Hald and Korsun, 1997). Our aDNA data suggest that the abundance of agglutinated foraminifera was higher than that shown by the fossil record. Three agglutinated taxa were detected in both the fossil and aDNA record: C. crassimargo, Reophax spp. and Spiroplectammina spp. (Tables S1 and S2). However, only $C$. crassimargo was detected by both approaches in the corresponding layers. Reophax spp. and Spiroplectammina spp. sequences were recorded in all the examined samples, but they were relatively rare or absent in the fossil material (Pawłowska et al., 2014), probably due to the degradation of their tests. Korsun and Hald (2000) regarded S. biformis and S. earlandi as typical for glaciomarine habitats. They noticed an increase in the abundance of those agglutinated species off glacier. Korsun et al. (2005) 
and Hald and Korsun (1997) reported Reophax spp. and Spiroplectammina spp. in the outer parts of the glacially fed fjords of Svalbard and Novaya Zemlya. Zajączkowski et al. (2010) noted a decrease in the abundance of agglutinated foraminifera in Hornsund with increasing water turbidity. Thus, the presence of those species might indicate a glacier-distant environment.

Furthermore, the transition to the LIA between $\sim$ AD 1600 and $\sim 1800$ was well marked by the increase in the percentage of monothalamous foraminifera aDNA sequences (Fig. 6). Monothalamids are highly adaptable and occur in environments where conditions may be extreme (Gooday, 2002; Sabbattini et al., 2010), which makes them effective colonizers. It is likely that the change in the hydrology and productivity in Hornsund at $\sim$ AD 1600 might have created a new ecological niche, which was effectively settled by monothalamids. The monothalamous assemblage during the early LIA (from $\sim \mathrm{AD} 1600$ to $\sim 1800$ ) was dominated by taxa belonging to clade BM, mainly from genus Bathysiphon (Fig. 6). Gooday et al. (2005) reported Bathysiphon sp. in two glacial influenced fjords, Van Mijenfjorden and Kongsfjorden, at glacier-distant sites. Moreover, a sharp peak of heavier $\delta^{13} \mathrm{C}$ was noted in Hornsund at $\sim \mathrm{AD} 1600$, which might suggest the short-term suppression of primary productivity that resulted in the presence of degraded organic matter and phytodetritus that seemed to be favourable for Bathysiphon sp. (Alve et al., 2010). The presence of sequences of Bathysiphon sp. and agglutinated Spiroplectammina spp. and Reophax spp. support our conclusion that at the onset of the LIA ( $\sim$ AD 1600 to $\sim 1800)$, the position of the glacier fronts was relatively distant to the fjord centre, which resulted in a low SAR and a low IRD flux, whereas the fjords' water masses were influenced by the ArW.

The transition to the LIA ( $\sim$ AD 1600 to $\sim 1800)$ was also marked by increased percentages of sequences assigned to the monothalamid clade D (mainly Hippocrepinella hirudinea) and to clade $\mathrm{O}$ (mainly Cedhagenia saltatus; Fig. 5). Cedhagenia saltatus is a species recently found by Gooday et al. (2011) in the Black Sea. Little is known about the environmental tolerance of $C$. saltatus. However, its presence in the area is strongly impacted by human activity, which suggests that it is an opportunistic species that has a high tolerance to environmental disturbance. Hipocrepinella hirudinea was noted in the fjords of Svalbard by Majewski et al. (2005) and Gooday et al. (2005). It appeared in the central and outer parts of the studied fjords, mainly in the shallow water sites. Korsun et al. (2005) noted the presence of the genus Hipocrepinella in Novaya Zemlya; however, it may not have referred to $H$. hirudinea. The scarce data on the ecological tolerances of $H$. hirudinea and $C$. saltatus precluded making any general conclusions.

\subsection{The late Little Ice Age ( AD 1800 to $\sim 1900)$}

The late LIA was characterized by an increased sediment accumulation rate and strongly fluctuating IRD delivery (Fig. 3). These changes were linked to changes in the particulate matter flux, which in subpolar fjords was governed by glacial meltwater discharge (Syvitski, 1989). Substantial amounts of suspended sediment and IRD might be released from glaciers during rapid deglaciation and during glacial surges (Koppes and Hallet, 2002). Moreover, sediment might be stored in the proglacial zones of land-based glaciers, from where it could be eroded, particularly under conditions of increased glacial meltwater runoff and increased precipitation (Szczuciński et al., 2009). Next, the sediment could be redeposited from the sublittoral zone by storm waves. During the LIA, glacial extent reached its Holocene maximum (D'Andrea et al., 2012); thus, calving and meltwater delivery could have occurred close to the central part of the fjord. Noticeably, the increase in the IRD delivery during the late LIA was not followed by an increase in the mean grain size, as was observed in both the precedent and following periods. It is likely that the amount of fine-grained sediment delivered to the sea bottom significantly exceeded the amount of coarse ice-rafted sediment (i.e. IRD) and, consequently, almost no change in the mean grain size was observed.

Our data showed a 20-fold increase in the foraminiferal flux at $\sim \mathrm{AD} 1800$ (Fig. 3), whereas the species diversity was relatively low due to the dominance of glaciomarine species, especially E. excavatum and C. reniforme (Figs. 4 and 5). As a consequence of the maximal range of the glaciers, conditions throughout the fjord became more glacier-proximal.

The aDNA revealed the dramatic increase in the percentage of sequences of monothalamous foraminifera at $\sim$ AD 1900 (Fig. 6). Previous studies have revealed that the distribution of monothalamids in Svalbard was closely related to the distance from the glacier at the head of the fjord. The study conducted by Majewski et al. (2005) in Kongsfjorden and Isfjorden showed a distinctive faunal gradient along the fjord axes, with three different monothalamous assemblages at subtidal, shallow-water and deep-water sites. Korsun et al. (2005) and Korsun and Hald (1998, 2000) reported that allogromiids constituted up to $99 \%$ of living foraminifera in the stations close to the glacier termini in Novaya Zemlya and Spitsbergen. Sabbattini et al. (2007) attributed the occurrence of monothalamids in the Svalbard region to inputs of fresh water and a high, changeable sedimentation rate. Gooday et al. (2005) noted that the inner parts of Tempelfjorden and Kongsfjorden, fjords headed by tidewater glaciers, were dominated by organic-walled allogromiids and saccamminids. This was reflected in our data as the percentage of allogromiids (mainly Micrometula sp.) increased significantly from $40 \%$ at $\sim \mathrm{AD} 1850$ to $80 \%$ at $\sim \mathrm{AD} 1900$ (Fig. 5). Moreover, the late LIA and the early MW were marked by an increase in the percentage of sequences assigned to clade E, mainly Vellaria pellucidis. Majewski et 
al. (2005) noted the presence of Vellaria sp. in subtidal and shallow areas of the Spitsbergen fjords. The increase in the percentage of Micrometula sp. and V. pellucidis in the period of the highest glacial activity suggests that those species were potential indicators of glacier-proximal settings.

\subsection{The modern warming ( $\sim$ AD 1900 to present)}

The sedimentary record of the MW featured a decrease in the SAR and a lower but variable IRD flux (Fig. 3). Peaks in the IRD flux coincided with the increased mean grain size (Fig. 3). This trend was opposite to that of the late LIA, where no clear correlation between the IRD flux and mean grain size was observed. The post-LIA glacial retreat led to an increased distance between the coring station and the main tidewater glacier front. In the Spitsbergen fjords, finesized particles from glacial outflows are deposited close to the source (Szczuciński et al., 2009); therefore, the HF_2011 station was impacted mainly by ice-rafted, coarser particles. The IRD flux gradually diminished in the late 20th century, which was probably a result of retreat of the tidewater glaciers' fronts to the inner bays, which limited iceberg drift to the fjord centre. The most noticeable changes in the fossil foraminifera community occurred in the late 20th century, with the gradual increase in B. frigida and I. norcrossi and the decrease in C. lobatulus (Fig. 4). Islandiella norcrossi and $B$. frigida typically occupied the distal sections of the glacial fjords of Svalbard and Novaya Zemlya (Korsun et al., 2005; Hald and Korsun, 1997; Korsun and Hald, 2000; Pogodina, 2005). Steinsund (1994) linked the presence of I. norcrossi and $B$. frigida with high productivity related to a polar front position and seasonal sea-ice cover. Thus, we concluded that since the mid-20th century, Hornsund and the adjacent shelf remained under the influence of the AW, which formed a frontal zone with local waters. This conclusion is supported by the PC analysis, which showed that the significance of the $N$. labradorica FA was increasing during the 20th century (Fig. 5). Cibicidoides lobatulus is a relatively shallow-water species and takes advantage of vigorous bottom waters (Hald and Korsun, 1997; Lloyd, 2006); however, it is an epiphytic species that needs a hard substrate to stay attached to the bottom surface. Therefore, the decrease in the percentage of $C$. lobatulus could be connected to a decrease in the near-bottom currents and a low IRD flux and, consequently, an increase in the fine sediment fraction (Fig. 3). The increased abundance of species typical of glacier-distant faunas was followed by a decrease in the abundance of species considered to be bottom current indicators (Fig. 4). These results support our evidence for a rapid glacier retreat, coupled with the decreasing influence of glaciomarine sedimentation and enhanced productivity. It was also reflected in the molecular record, where the number of OTUs and the percentage of monothalamids decreased after $\sim$ AD 1920, reaching values similar to those during the MWP (Fig. 6). The second half of the 20th century was marked by a significant increase in the unassigned monothalamid sequences belonging to environmental clades. However, without an accurate identification of sequences, it is not possible to make any palaeoecological interpretations.

The use of the approach based on aDNA allows the hidden diversity of benthic foraminifera communities to be assessed and, therefore, the information based on traditional palaeoceanographic proxies to be refined. However, current methodological biases associated with the environmental DNA sequencing approach preclude comprehensive analyses of sequence abundance data. The aDNA data should be interpreted carefully as it is not possible to establish the direct relationship between the number of specimens and the number of ribosomal sequences. Some aspects of quantitative DNA analyses were discussed in Weber and Pawlowski (2013). One of the conclusions was that when the species is very abundant, its sequences are also numerous. Therefore, the genuinely dominant species might be associated with high sequence occurrences in the sequencing data.

\section{Conclusions and perspectives}

The main climatic fluctuations of the last millennium (the MWP, the LIA and the MW) were reflected in the fjord water mass balance and glacial activity. The marine environmental conditions during the MWP and the early LIA were relatively stable, with a low SAR and low IRD flux. The beginning of the LIA ( AD 1600) was poorly supported by the fossil record, but it was well evidenced in the aDNA data. It was marked by the increased percentage of sequences of monothalamous foraminifera, mainly Bathysiphon sp., which supports our assumption that the terminal positions of the glaciers were relatively distant at the onset of the LIA. The early LIA ( $\sim$ AD 1600 to $\sim 1800)$ was also marked by high percentages of $H$. hirudinea and $C$. saltatus. The late LIA (after $\sim \mathrm{AD} 1800$ ) was characterized by the increased proximity of tidewater glaciers' fronts, which increased sedimentation from suspension and from the icebergs; thus, conditions in the fjord centre became glacier-proximal. The end of the LIA ( $\sim$ AD 1900) was marked by increased percentage of Micrometula sp. and V. pellucidus. Those results revealed their potential as indicators of glacier-proximal environments, which were characterized by meltwater outflows, a high sedimentation rate and increased calving. During the MW, the major glaciers' fronts retreated rapidly to the inner bays, limiting the iceberg discharge to the fjord centre and causing the shift in the foraminiferal community reflected in the fossil and aDNA records.

The present study was the first attempt to implement an aDNA foraminiferal record for palaeoclimatic reconstruction. The data inferred from the molecular analyses correlated well with environmental changes. The aDNA record even revealed small environmental changes that were not clearly indicated by the fossil record. By including monothalamous foraminifera identified in the aDNA record, we con- 
siderably increased the number of potential proxy species. However, to fully benefit from this new source of information, it is essential to improve knowledge of the ecology of monothalamids. The positive results of the present study encourage further applications of ancient foraminiferal DNA sequences to reconstruct past environmental changes in polar regions.

\section{The Supplement related to this article is available online at doi:10.5194/cp-12-1459-2016-supplement.}

Acknowledgements. This study was supported by the "Scientific Exchange Programme between the New Member States of the EU and Switzerland" (Sciex-NMS, project 10.140) and by the Swiss National Science Foundation (grant 31003A_140766). The study was also funded by the Polish Ministry and Higher Education (grant nos. 2013/11/B/ST10/00276 and 2014/12/T/ST10/00675). The authors thank the crew of R/V Oceania for their assistance during the fieldwork. Mateusz Ostrowski is thanked for helping with the granulometric analysis.

Edited by: L. Beaufort

Reviewed by: S. Korsun and one anonymous referee

\section{References}

Alve, E.: Benthic foraminiferal responses to absence of fresh phytodetritus: A two - year experiment, Mar. Micropaleontol., 76, 67-76, 2010.

Berben, S. M. P., Husum, K., Cabedo-Sanz, P., and Belt, S. T.: Holocene sub-centennial evolution of Atlantic water inflow and sea ice distribution in the western Barents Sea, Clim. Past, 10, 181-198, doi:10.5194/cp-10-181-2014, 2014.

Blaauw, M.: Methods and code for "classical" age-modelling of radiocarbon sequences, Quat. Geochronol., 5, 512-518, 2010.

Blott, S. J. and Pye, K.: GRADISTAT: a grain size distribution and statistics package for the analysis of unconsolidated sediments, Earth Surf. Proc. Land., 26, 1237-1248, 2001.

Boere, A. C., Rijpstra, W. I. C., De Lange, G. J., Sinninghe Damsté, J. S., and Coolen, M. J. L.: Preservation potential of ancient plankton DNA in Pleistocene marine sediments, Geobiology, 9, 377-393, 2011.

Cedhagen, T., Goldstein, S. T., and Gooday, A. J.: A theme issue of the biology and biodiversity of "allogromiid" foraminifera, J. Foramin. Res., 32, 331-333, 2002.

Coolen, J. M. L., Boere, A., Abbas, B., Baas, M., Wakeham, S. G., and Sinninghe Damsté, J. S.: Ancient DNA derived from alkenone-biosynthesizing haptophytes abd other algae in Holocene sediments from the Black Sea, Paleoceanography, 21, PA1005, doi:10.1029/2005PA001188, 2006.

Coolen, M. J. L, Orsi, W. D., Balkema, C., Quince, C., Harris, K., Sylva, S. P., Filipova-Marinova, M., and Giosan, L.: Evolution of the plankton paleome in the Black Sea from the Deglacial to Anthropocene, P. Natl. Acad. Sci. USA, 110, 8609-8614, doi:10.1073/pnas.1219283110, 2013.
Cottier, F. R., Tverberg, V., Inall, M. E., Svendsen, H., and Griffiths, C.: Water mass modification in an Arctic fjord through cross-shelf exchange: The seasonal hydrography of Kongsfjorden, Svalbard, J. Geophys. Res., 110, C12005, doi:10.1029/2004JC002757, 2005.

D’Andrea, W. J., Vaillencourt, D. A., Balascio, N. L., Werner, A., Roof, S. R., Retelle, M., and Bradley, R. S.: Mid Little Ice Age and unprecedented recent warmth in 1800 year sediment lake record from Svalbard, Geology, 40, 1007-1010, 2012.

Divine, D., Isaksson, E., Martma, T., Meijer, H. A. J., Moore, J., Pohjola, V., van de Wal, R. S. W., and Godtliebsen, F.: Thousand years of winter surface air temperature variations in Svalbard and northern Norway reconstructed from ice-core data, Polar Res., 30, 7379, doi:10.3402/polar.v30i0.7379, 2011.

Gooday, A. J.: Organic-walled allogromiids: aspects of their occurrence, diversity and ecology in marine habitats, J. Foramin. Res., 32, 384-399, 2002.

Gooday, A. J., Bowser, S. S., Cedhagen, T., Cornelius, N., Hald, M., Korsun, S., and Pawłowski, J.: Monothalamous foraminiferans and gromiids (Protista) from western Svalbard: A preliminary survey, Mar. Biol. Res., 1, 290-312, 2005.

Gooday, A. J., Anikeeva, O. V., and Pawlowski, J.: New genera and species of monothalamous Foraminfera from Balaclava and Kazach'ya Bays (Crimean Peninsula, Black Sea), Mar. Biodiv., 41, 481-494, 2011.

Gouy, M., Guindon, S., and Gascuel, O.: SeaView Version 4: a multiplatform graphical use of interface for sequence aligment and phylogenetic tree building, Mol. Biol. Evol., 27, 221-224, 2010.

Groot, D. E., Aagaard-Sørensen, S., and Husum, K.: Reconstruction of Atlantic water variability during the Holocene in the western Barents Sea, Clim. Past, 10, 51-62, doi:10.5194/cp-10-51-2014, 2014.

Hagen, J. O., Liestøl, O., Roland, E., and Jørgensen, T.: Glacier atlas of Svalbard and Jan Mayen, Norsk Polarinstitutt Meddelelser, 129, 1993.

Hald, M. and Korsun, S.: Distribution of modern benthic foraminifera from fjords of Svalbard, European Arctic, J. Foramin. Res. 27, 101-122, 1997.

Hald, M., Anderson, C., Ebbesen, H., Janstein, E., KlitgaardKristensen, D., Risebrobakken, B., Salomonsen, G. R., Sarnthein, M., Sejrup, H. P., and Telford, R. J.: Variations in temperature and extent of Atlantic Water in the northern North Atlantic during the Holocene, Quaternary Sci. Rev. 26, 3423-3440, 2007.

Humlum, O., Elberling, B., Hormes, A., Fjordheim, K., Hansen, O. H., and Heinemeier, J.: Late Holocene glacier growth in Svalbard, documented by subglacial relict vegetation and living soil microbes, Holocene 15, 396-407, 2005.

Hunt, A. S. and Corliss, B. H.: Distribution and microhabitats of living (stained) benthic foraminifera from the Canadian Arctic Archipelago, Mar. Micropaleontol., 20, 321-346, 1993.

Isaksson, E., Hermanson, M., Hicks, S., Igarashi, M., Kamiyama, K., Moore, J., Motoyama, H., Muir, D., Pohjola, V., Vaikmäe, R., van de Wal, R. S. W., and Watanabe, O.: Ice cores from Svalbard - useful archives of past climate and pollution history, Phys. Chem. Earth., 28, 1217-1228, 2003.

Ivanova, E. V., Ovsepyan, E. A., Riserbroakken, B., and Vetrov, A. A.: Downcore distribution of living calcareous foraminifera and stable isotopes in western Barents Sea, J. Foramin. Res., 38, 337509, 2008. 
Jernas, P., Klitgaard-Kristensen, D., Husum, K., Wilson, L., and Koç, N.: Paleoenvironmental changes of the last two millennia on the western and northern Svalbard shelf, Boreas, 42, 236-255, 2013.

Kelly, M., Funder, S., Houmark-Nielsen, M., Knudsen, K. L., Kronborg, C., Landvik, J., and Sorby, L.: Quaternary glacial and marine environmental history of northwestern Greenland: a review and reappraisal, Quaternary Sci. Rev., 18, 373-392, 1999.

Koppes, M. N. and Hallet, B.: Influence of rapid glacial retreat on the rate of erosion by tidewater glaciers, Geology, 30, 47-50, 2002.

Korsun, S. and Hald, M.: Modern benthic Foraminifera off Novaya Zemlya tidewater glaciers, Arct. Antarct. Alp. Res., 30, 61-77, 1998.

Korsun, S. and Hald, M.: Seasonal dynamics of benthic foraminifera in a glacially fed fjord of Svalbard, European Arctic., J. Foramin. Res., 30, 251-271, 2000.

Korsun, S., Pogodina, I. A., Forman, S. L., and Lubinski, D. J.: Recent foraminifera in glaciomarine sediments from three arctic fjords of Novaja Zemlja and Svalbard, Polar Res., 14, 15-31, 2005.

Kubischta, F., Knudsen, K. L., Ojala, A. E., and Salonen, V.-P.: Holocene benthic foraminiferal record from a high-arctic fjord, Nordaustlandet, Svalbard, Geogr. Ann. A, 93, 227-242, 2011.

Łącka, M., Zajączkowski, M., Forwick, M., and Szczucinski, W.: Late Weichselian and Holocene palaeoceanography of Storfjordrenna, southern Svalbard, Clim. Past, 11, 587-603, doi:10.5194/cp-11-587-2015, 2015.

Lejzerowicz, F., Voltski, I., and Pawlowski, J.: Identifying active foraminifera in the Sea of Japan using metatranscriptomic approach, Deep-Sea Res., 86-87, 214-220, 2013a.

Lejzerowicz, F., Esling, P., Majewski, W., Szczuciński, W., Decelle, J., Obadia, C., Martinez Arbizu, P., and Pawlowski, J.: Ancient DNA complements microfossil record in deep-sea subsurface sediments, Biol. Lett., 9, 20130283, doi:10.1098/rsbl.2013.0283, $2013 b$.

Linder, L., Marks, L., and Szczęsny, R.: Quaternary landforms and sediments, and morphogenetic evolution of TreskelenHyrnefjellet-Kruseryggen area, Wedel Jarlsberg Land, Spitsbergen, Pol. Polar Res., 11, 389-400, 1990.

Lloyd, J. M.: Modern distribution of benthic foraminifera from Disco Bugt, West Greenland, J. Foramin. Res., 36, 315-331, 2006.

Lund, D. C., Lynch-Stieglitz, J., and Curry, W. B.: Gulf Stream density structure and transport during the past millennium, Nature, 444, 601-604, 2006.

Majewski, W. and Zajączkowski, M.: Benthic foraminifera Adventfjorden, Svalbard: Last 50 years of local hydrographic changes, J. Foramin. Res., 37, 107-124, 2007.

Majewski, W., Pawłowski, J., Zajączkowski, M.: Monothalamous foraminifera from West Spitsbergen fjords: a brief overview, Pol. Polar Res., 26, 269-285, 2005.

Majewski, W., Szczuciński, W., and Zajączkowski, M.: Interactions of Arctic and Atlantic water-masses and associated environmental changes during the last millennium, Hornsund, Boreas, 38, 529-544, 2009.

Malmgren, B. A. and Haq, B. U.: Assessment of quantitative techniques in paleobiogeography, Mar. Micropaleontol., 7, 213-236, 1982.
Mangerud, J., Bondevik, S., Gulliksen, S., Hufthammer, A. K., and Høseter, T.: Marine ${ }^{14} \mathrm{C}$ reservoir ages for 19 th century whales and mollusks from the North Atlantic, Quaternary Sci. Rev., 25, 3228-3245, 2006

Marks, L. and Pękala, K.: New datings of Quaternary sediments from Bogstranda and Treskelodden, southern Spitsbergen, B. Pol. Acad. Sci.-Earth., 34, 419-425, 1986.

Oerlemans, J.: Extracting a climate signal from 169 glacier records, Science, 308, 675-677, 2005.

Pälli, A., Moore, J. C., Jania, J., and Głowacki, P.: Glacier changes in southern Spitsbergen, Svalbard, 1901-200, Ann. Glaciol., 37, 219-225, 2003.

Pawlowski J. and Lecroq, B.: Short rDNA barcodes for species identification in Foraminifera, J. Eukaryot. Microbiol., 57, 197502, 2010.

Pawlowski, J., Holzmann, M., Berney, C., Fahrni, J., Cedhagen, T., and Bowser, S. S.: Phylogeny of alogromiid Foraminifera inferred from SSU rRNA gene sequences, J. Foramin. Res., 32, 334-343, 2002.

Pawlowski, J., Christen, R., Lecroq, B., Bachar, D., Shahbazkia, H. R., Amaral-Zettler, L., and Guillou, L.: Eukaryotic richness in the abyss: Insights from pyrotag sequencing, PLoS ONE, 6, e18169, doi:10.1371/journal.pone.0018169, 2011.

Pawłowska, J., Lejzerowicz, F., Esling, P., Szczuciński, W., Zajączkowski, M., and Pawlowski, J.: Ancient DNA sheds new light on the Svalbard foraminiferal fossil record from the last millennium, Geobiology, 12, 277-288, 2014.

Pogodina, I. A.: Benthic Foraminifera in Hornsund fjord (West Spitsbergen), Oceanology, 45, 559-566, 2005.

Rasmussen, T. L., Forwick, M., and Mackensen, A.: Reconstruction of inflow of Atlantic Water to Isfjorden during the Holocene: Correlation to climate and seasonality, Mar. Micropaleontol., 94 95, 80-90, 2012.

Reimer, P. J., Bard, E., Bayliss, A., Beck, W. J., Blackwell, P. G., Ramsey, C. B., Buck, C. E., Cheng, H., Edwards, R. L., Friedrich, M., Grootes, P. M., Guilderson, T. P., Haflidason, H., Hajdas, I., Hatté, C., Heaton, T. J., Hoffman, D. L., Hogg, A. G., Hughen, K. A., Kaiser, K. F., Kromer, B., Manning, S. W., Niu, M., Reimer, R. W., Richards, D. A., Scott, E. M., Southon, J. R., Staff, R. A., Turney, C. S. M., and van der Plicht, J.: IntCal13 and Marine13 radiocarbon age calibration curves, 0-50,000 years cal BP, Radiocarbon, 55, 1869-1887, 2013.

Sabbattini, A., Morigi, C., Negri, A., and Gooday, A. J.: Distribution and biodiversity of stained Monothalamous foraminifera from Tempelfjord, Svalbard, J. Foramin. Res., 37, 93-106, 2007.

Sabbattini, A., Bonatto, S., Gooday, A. J., Morigi, C., Pancotti, I., Pucci, F., and Negri, A.: Modern benthic foraminifers at Northern shallow sites of Adriatic Sea and soft-walled, monothalamous taxa: a brief overview, Micropaleontology, 59, 359-376, 2010.

Steinsund, P. I.: Distribution of calcareous benthic foraminifera in recent sediments of the Barents and Kara Sea, PhD Thesis, University of Troms $\varnothing$, Norway, 1994.

Stuiver, M. and Reimer, P. J.; Extended ${ }^{14} \mathrm{C}$ database and revised CALIB radiocarbon calibration program, Radiocarbon, 35, 215 230, 1993.

Svendsen, H., Beszczyńska-Møller, A., Hagen, J. O., Lefauconnier, B., Tverberg, V., Gerland, S., Ørbæk, J. B., Bischof, K., Papucci, C., Zajączkowski, M., Azzolini, R., Bruland, O., Wiencke, C., Winther, J.-G., and Dallmann, W.: The physical environment of 
Kongsfjorden-Krossfjorden, an Arctic fjord system in Svalbard, Polar Res., 21, 133-166, 2002.

Syvitski, J. P. M.: On the deposition of sediment within glacierinfluenced fjords: oceanographic controls, Mar. Geol., 85, 301329, 1989.

Szczuciński, W., Schellter, G., and Zajączkowski, M.: Sediment accumulation rates, geochemistry and provenance in complex High Arctic fjord, Hornsund, Svalbard, in: Sediments, Morphology and Sedimentary Processes on Continental Shelves, edited by: Li, M., Sherwood, C., and Hill, P., IAS Special Publication, Wiley-Blackwell Publishing, 2006.

Szczuciński, W., Zajączkowski, M., and Scholten, J.: Sediment accumulation rates in subpolar fjords - impact of post-Little Ice Age glaciers retreat, Billefjorden, Svalbard, Estuar. Coast. Shelf S., 85, 345-356, 2009.

Voltski, I., Korsun, S., and Pawlowski, J.: Toxisarcon taimyr sp. nov., a new large monothalamous foraminifer from the Kara Sea inner shelf, Mar. Biodiv., 44, 213-221, 2014.
Wanamaker Jr., A. D., Butler, P. G., Scourse, J. D., Heinemeier, J., Eiríksson, J., Knudsen K. L., and Richardson C. A.: Surface changes in the North Atlantic meridional overturning circulation during the last millennium, Nat. Commun., 3, 899, doi:10.1038/ncomms1901, 2012.

Weber, A. A.-T. and Pawlowski, J.: Can abundance of Protists be inferred from sequence data: A case study of Foraminifera, PLoS ONE, 8, e56739, doi:10.1371/journal.pone.0056739, 2013.

Wollenburg, J. E. and Kuhnt, W.: The response of benthic foraminifers to carbon flux and primary production in the Arctic Ocean, Mar. Micropaleontol., 40, 189-231, 2000.

Zajączkowski, M., Szczuciński, W., Jernas, P., and Plessen, B.: Benthic foraminifera in Hornsund - implications for paleoenvironmental reconstructions, Pol. Polar Res., 31, 349-375, 2010.

Ziaja, W.: Glacial recession in Sørkappland and central Nordenskiöldland, Spitsbergen, Svalbard, during the 20th century, Arct. Antarct. Alp. Res., 33, 36-41, 2001. 